\title{
Food Preparation
}

For PCB-exposed fish, fish food was spiked by suspending a known quantity of each PCB Aroclor standard (1:1:1 ratio), and PCB 202 and 209 (10 $\mu \mathrm{g} / \mathrm{g}$ of fish food for each Aroclor mixture and $0.5 \mu \mathrm{g} / \mathrm{g}$ of fish food of each of PCB 202 and 209) in $500 \mathrm{ml}$ of hexane with $250 \mathrm{~g}$ of commercial fish food (3 Vigor Sinking Fish Feed, Corey Feed Mills, Fredericton, NB, Canada). For CYP-exposed fish (CYP 1A and CYP 2B), an additional mixture of PCB congeners known to induce CYP 1A enzyme activity (PCBs 77, $126 \& 169 ; 10 \mathrm{ng} / \mathrm{g}$ of fish food for each) or PCB congeners known to induce CYP 2B enzyme activity in mammals (PCBs 87, 99, 101, $153,180,183 \& 194 ; 10 \mathrm{ng} / \mathrm{g}$ of fish food for each) were added to the food. Food and solvent mixtures were evaporated to dryness under pressure, and stored at $-20{ }^{\circ} \mathrm{C}$ in sealed containers. Control food and food used for the depuration phase were treated in an identical manner but without the addition of PCB congeners. Concentration of PCBs were determined in food (Table 1, reported as homologue group concentrations) using the same analytical techniques used to determine concentrations in the rainbow trout tissue. Concentrations of PCBs in PCB and CYP (1A and 2B)- dosed food were high compared to concentrations in prey species from the wild, but were used to ensure levels of potential OH-PCB bioformed would be in high enough concentration to be detected.

PCB analysis

Frozen whole fish (carcass), were allowed to thaw at room temperature prior to extraction. PCB extraction and analysis followed previously established methods [1]. Briefly, samples were homogenized using an AE-G225 food processor (American Eagle, Chicago, Illinois). Extractions were performed using a Dionex ASE 200 extractor using $33 \mathrm{~mL}$ stainless steel extraction cells. PCBs 30 and 204 were added as internal standards. Extracts were 
collected and passed through an Allen funnel, rinsed with DCM and reduced in volume. Lipids were determined gravimetrically using $10 \%$ of the extract and remaining lipids removed by acidified silica gel chromatography. PCBs were eluted with 15\% DCM in hexane and evaporated to $1 \mathrm{~mL}$ final volume.

Samples were analyzed on a Hewlett-Packard (Wilmington, DE, USA) 5890 gas

chromatograph with a ${ }^{63} \mathrm{Ni}$-electron capture detector. Compound separation was completed using a $60 \mathrm{~m} \times 0.25 \mathrm{~mm}$ (internal diameter) DB-5 column (internal film thickness $0.25 \mu \mathrm{m}$; J\&W Scientific, Folsom, CA, USA) following established methodology [2] with $\mathrm{H}_{2}$ carrier gas (at a constant flow rate of $0.91 \mathrm{ml} / \mathrm{min}$ ) and nitrogen makeup gas (detector temperature $325^{\circ} \mathrm{C}$ ). Sample quantification was performed using multiple external standards obtained from the National Laboratory for Environmental Testing [3]. The method detection limit (MDL) for individual PCB congeners was $0.1 \mathrm{ng} / \mathrm{g}$ wet weight (w.w.) based on signal to noise ratio of 10 . In the case where the congeners were found in blanks, three times the standard deviations of the analytes in the blanks were used to calculate the MDL. Recoveries of PCB congeners were 82.36 $\% \pm 2.11 \%$ (mean \pm standard error $(\mathrm{SE}))$ based on PCB 30 and concentrations were corrected for recovery.

\section{OH-PCB Analysis}

The method used for OH-PCB extraction, clean-up and analysis of PCBs and OH-PCBs in plasma is detailed previously [4]. Briefly, plasma samples were thawed, spiked with ${ }^{13} \mathrm{C}_{12^{-}}$ labelled recovery standards and non-labeled PCB internal standards (PCBs 30 and 204), mixed and allowed to equilibrate. Proteins were denatured, and contaminants were extracted using a conventional liquid:liquid extraction technique. Organic and aqueous fractions were reduced to a 
final volume of approximately $1000 \mu \mathrm{L}$ and $100 \mu \mathrm{L}$ respectively. Volume correction was determined by weight for both aqueous and organic fractions.

Organic phases were analyzed and followed the same methods used for PCB analysis in whole fish tissue. The average percent recovery of the organic phase (PCBs in plasma) was 79.8 $\pm 1.6 \%$ (mean $\pm 1 \mathrm{SE}$ ) based on PCBs 30 and 204 . The resulting aqueous phase extracts were analyzed by high resolution GC/MS on a Micromass Ultima mass spectrometer coupled to an Agilent 6890 GC equipped with a CTC A200s autosampler. The GC injection port was configured for split/splitless injection at a temperature of $280{ }^{\circ} \mathrm{C}$. Gas chromatographic separation prior to MS was achieved using a $60 \mathrm{~m}$ X $0.25 \mathrm{~mm}$ X $0.25 \mathrm{~mm}$ DB5 MS column. The GC column was maintained at $80{ }^{\circ} \mathrm{C}$ for $1 \mathrm{~min}$, then ramped at $20{ }^{\circ} \mathrm{C} / \mathrm{min}$ to $170{ }^{\circ} \mathrm{C}$, held for 12 min and then ramped at $2{ }^{\circ} \mathrm{C} / \mathrm{min}$ to $285{ }^{\circ} \mathrm{C}$ and held for an additional $24 \mathrm{~min}$. Helium was used as the carrier gas in constant pressure mode. Sample ionization was performed by electron impact (EI) at an electron voltage ranging from 30 to $40 \mathrm{eV}$ depending on the optimization parameters of the instrument. Source temperature was $270{ }^{\circ} \mathrm{C}$ and the resolving power of the analyzer was 10,000 . The mass spectrometer was operated in SIM mode using a total of 8 function groups to analyze the suite of $\mathrm{OH}$ PCB congeners. There are 837 theoretically possible mono-OH-PCB congener structures compared to 209 for PCBs. Forty-seven OH-PCB congeners were commercially available as authentic standards at the time of analysis. The quantification of $\mathrm{OH}-\mathrm{PCB}$ s for which standards were available (identified $\mathrm{OH}-\mathrm{PCBs}$ ) was conducted using external calibration curves. The high selectivity of the high resolution HRGC/HRMS permitted the identification of numerous unknown peaks as OH-PCBs. Unknown peaks that matched the isotopic ratio of primary and secondary ions were determined as unidentified $\mathrm{OH}-\mathrm{PCB}$ homologues. The quantification of OH-PCB homologues was accomplished using an average 
response factor based on the native standard within the same chlorine-substituted homolog group. MDLs for OH-PCBs ranged between 0.1 and $4 \mathrm{ng} / \mathrm{g}$ w.w. based on the same calculations as for PCBs. Five ${ }^{13} \mathrm{C}$ internal standards $\left({ }^{13} \mathrm{C} 4-\mathrm{OH}-12,{ }^{13} \mathrm{C} 4-\mathrm{OH}-29,{ }^{13} \mathrm{C} 4-\mathrm{OH}-61,{ }^{13} \mathrm{C} 4-\mathrm{OH}-\right.$ 120 and $\left.{ }^{13} \mathrm{C} 4-\mathrm{OH}-187\right)$ from various homologue groups were used to determine the recovery of $\mathrm{OH}-\mathrm{PCB}$ in the plasma. OH-PCB concentration data were recovery corrected in order to compare homologue group levels. No OH-PCBs were detected in the food.

EROD Analysis

Analysis of liver samples for EROD enzyme activity was carried out with post-

mitochondrial supernatants as described previously [5] with modifications [6]. Microsomes were prepared following established methodology [7] and stored at $-80{ }^{\circ} \mathrm{C}$ until analysis. 


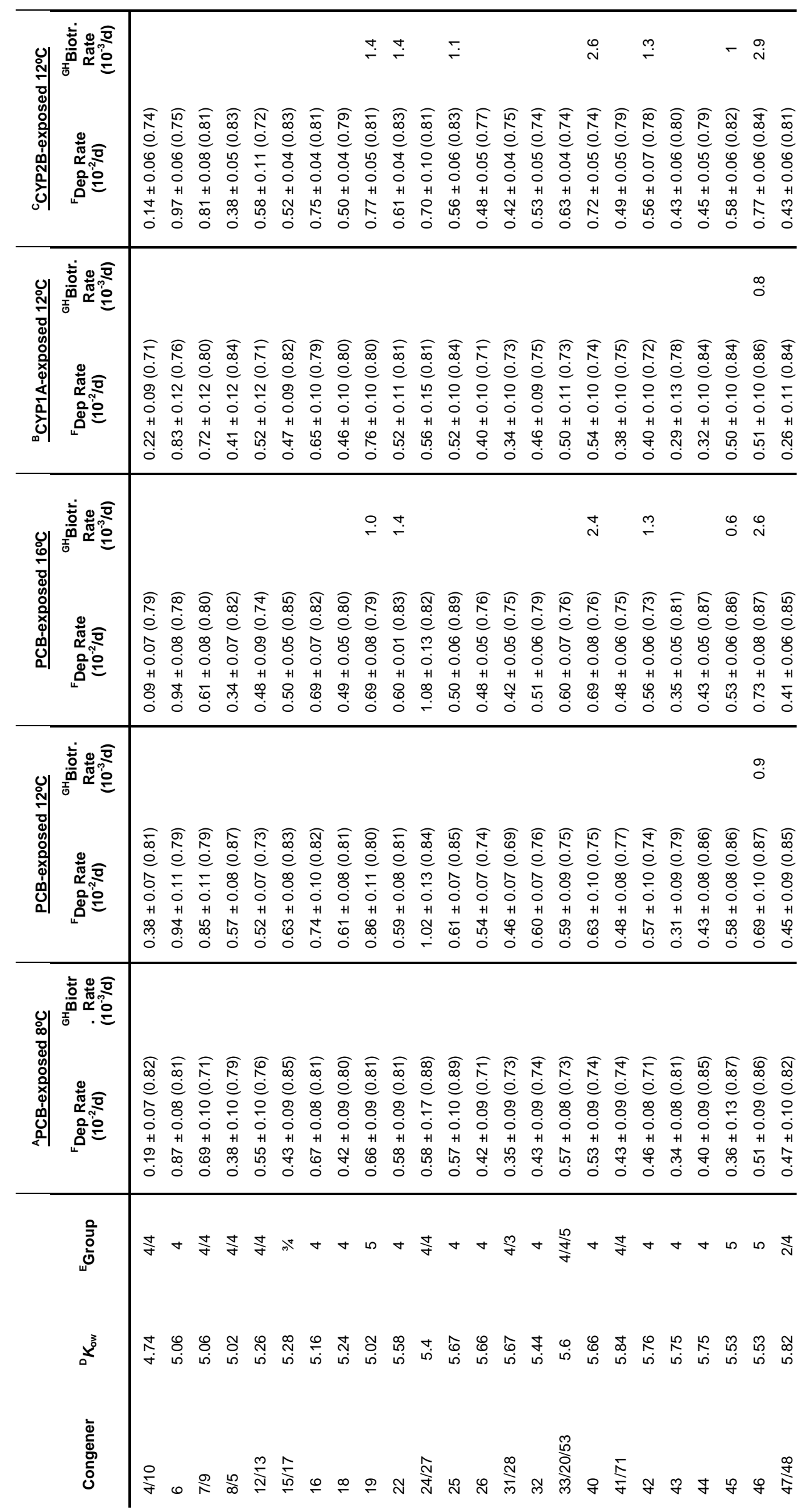




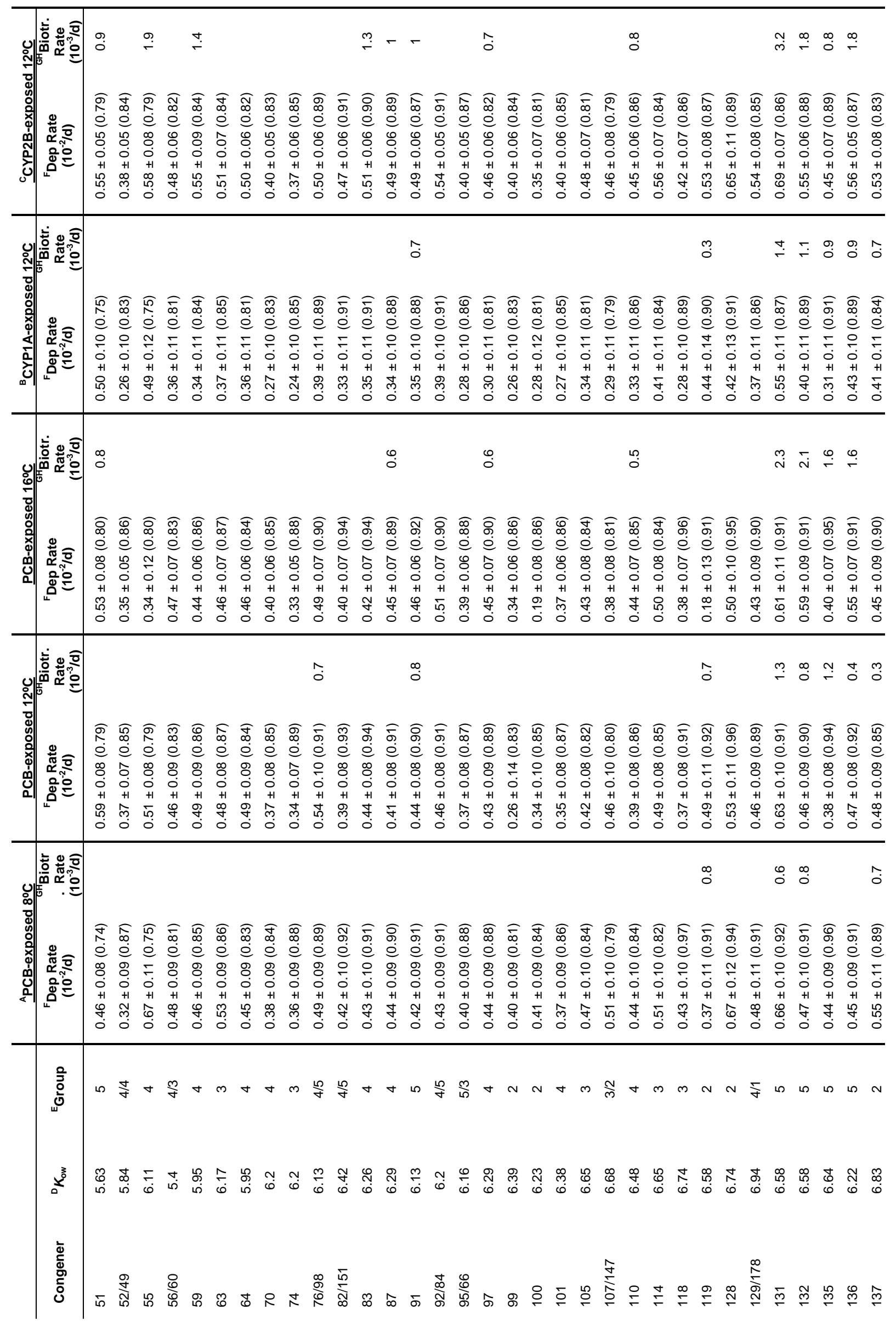




\begin{tabular}{|c|c|c|}
\hline 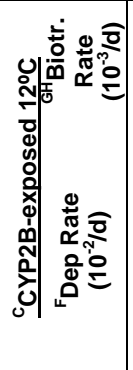 & 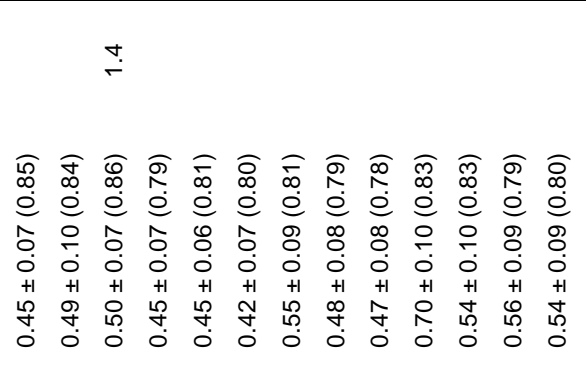 & 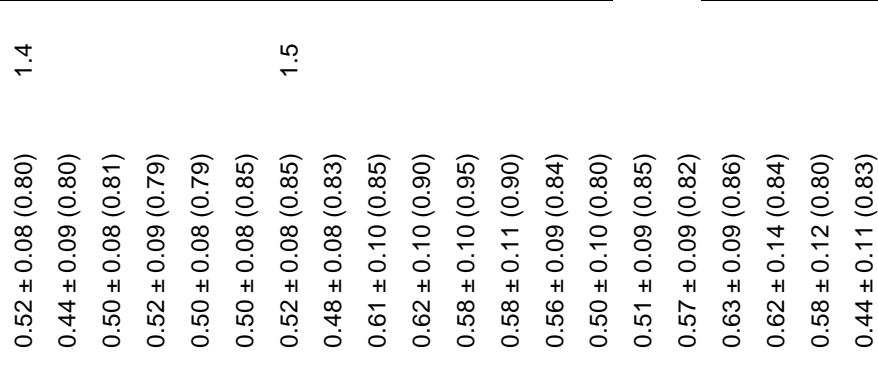 \\
\hline 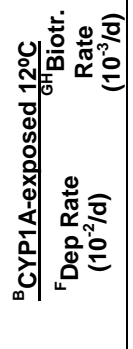 & 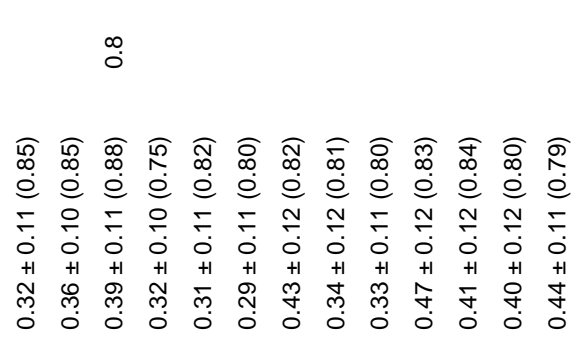 & 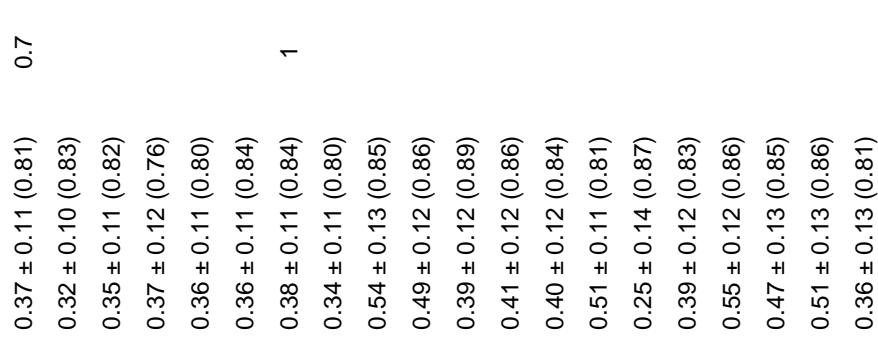 \\
\hline 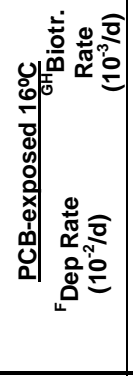 & 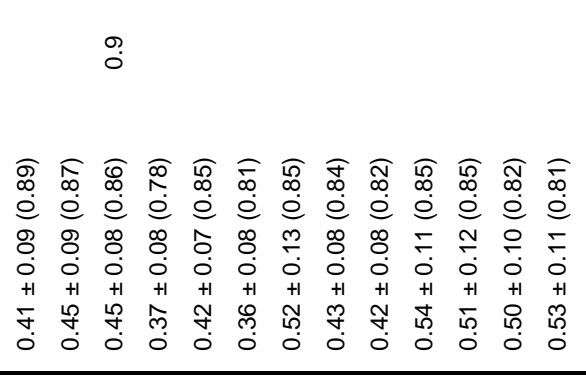 & 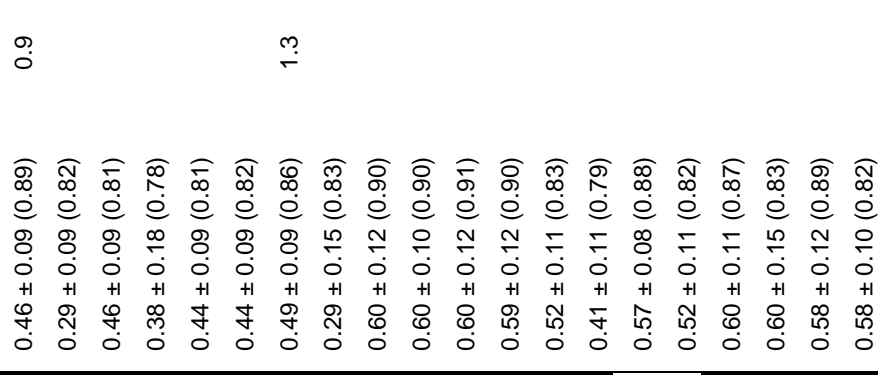 \\
\hline 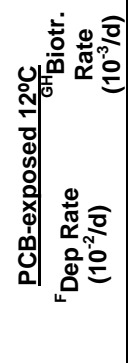 & 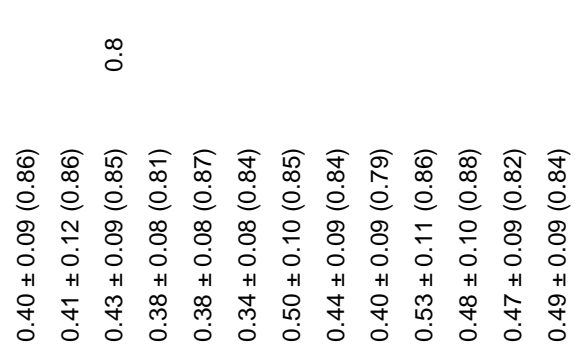 & 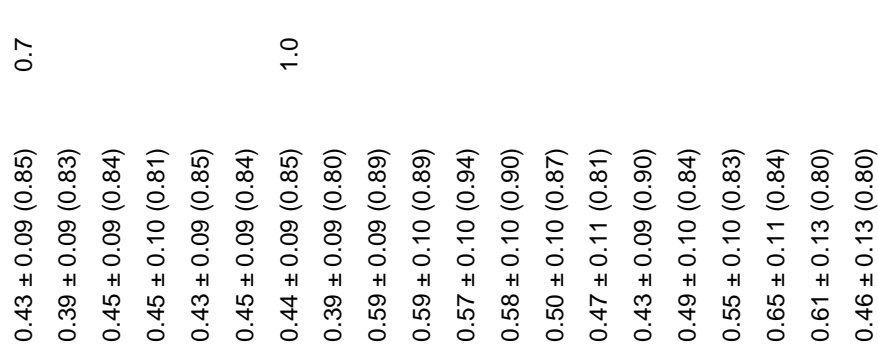 \\
\hline 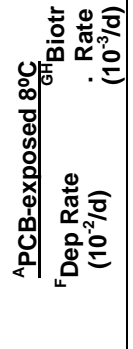 & 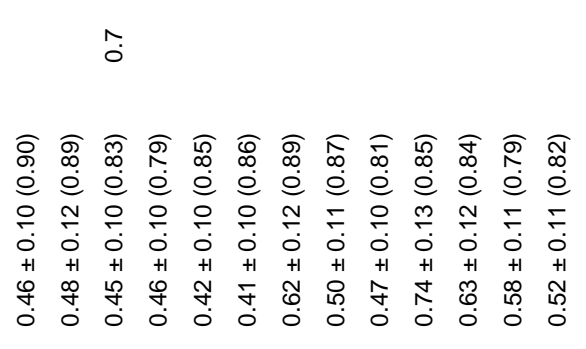 & 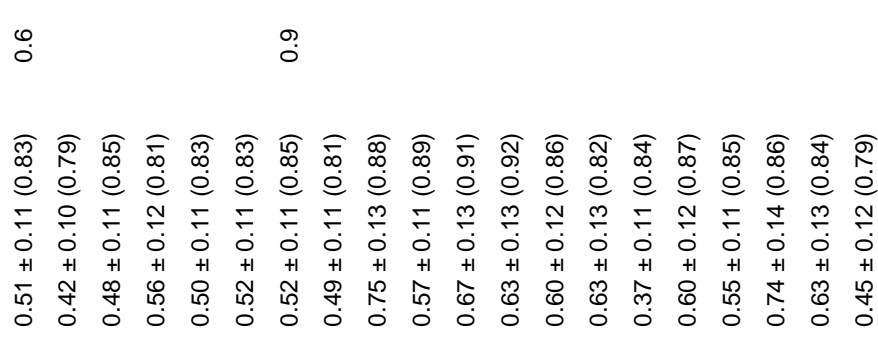 \\
\hline $\begin{array}{l}\circ \\
\frac{0}{0} \\
\overline{0}\end{array}$ & 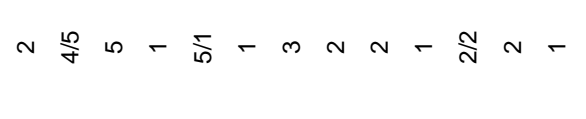 & $-\sim \Sigma-r$ \\
\hline$x^{3}$ & 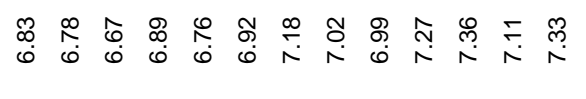 & 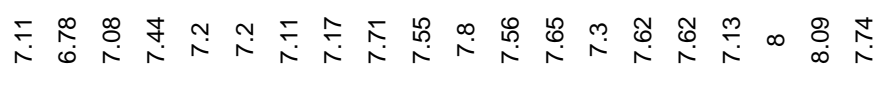 \\
\hline 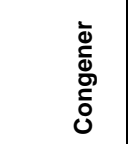 & 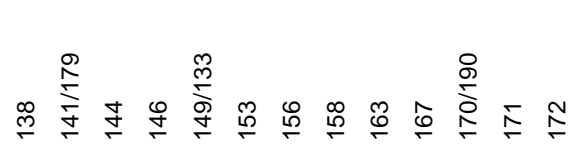 & 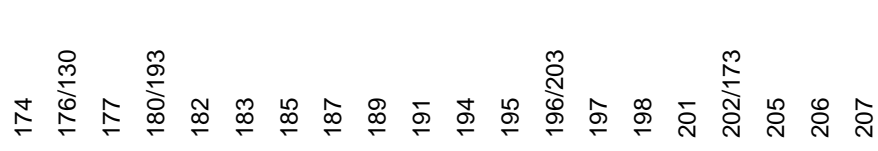 \\
\hline
\end{tabular}




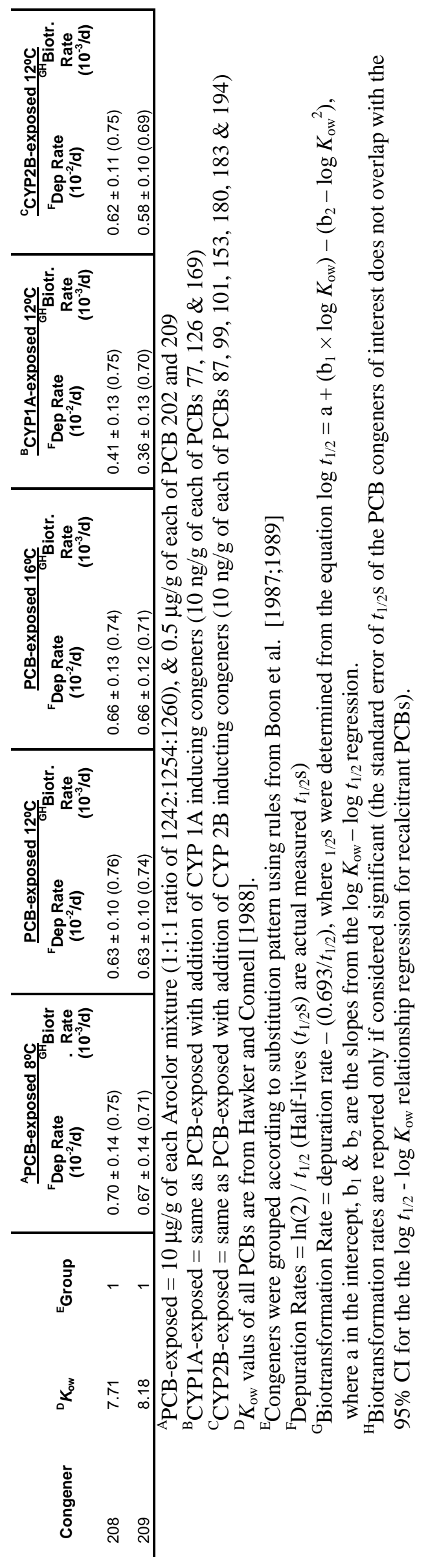




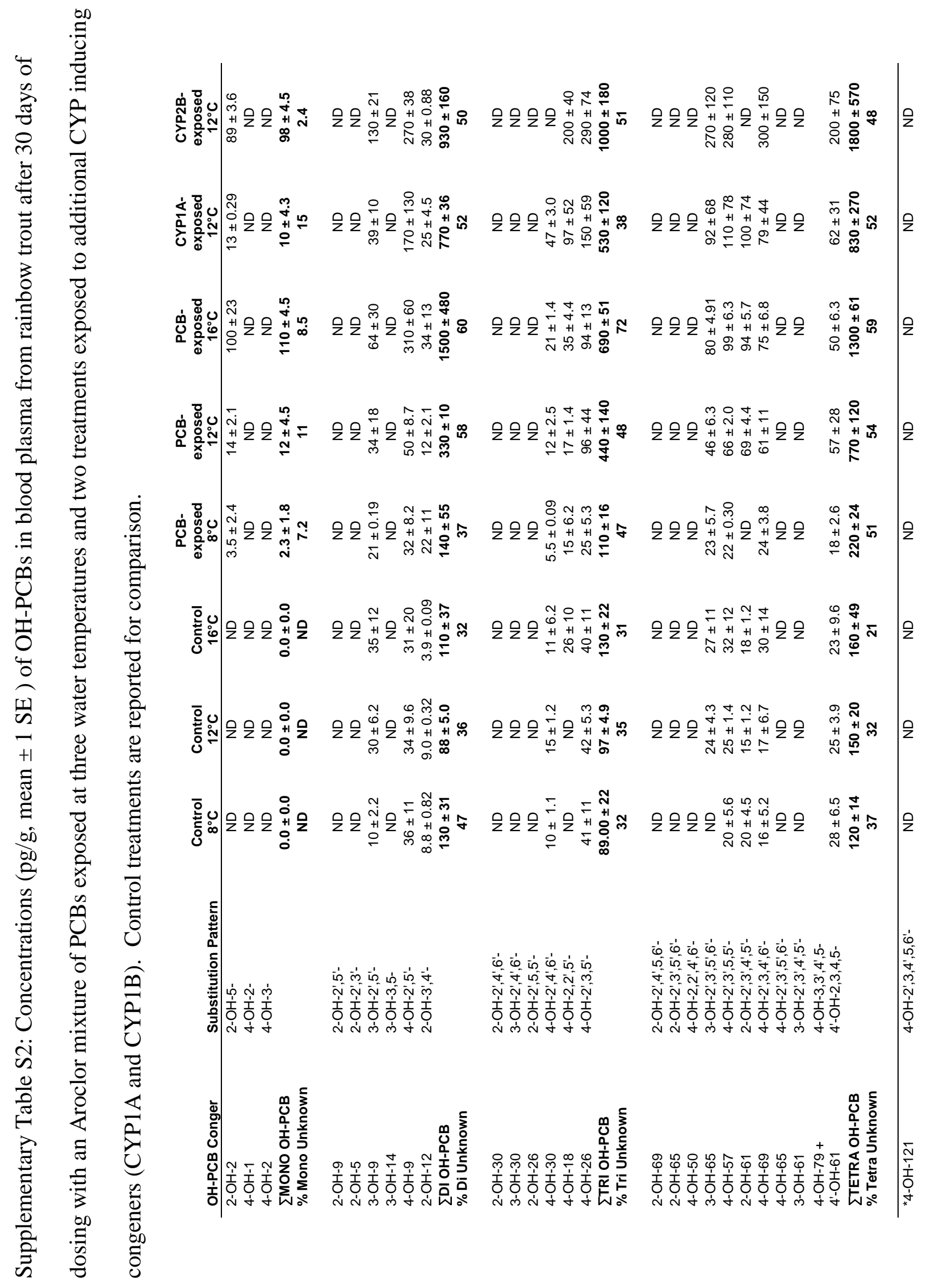




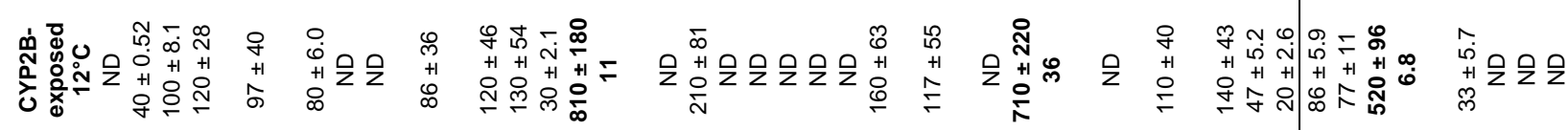

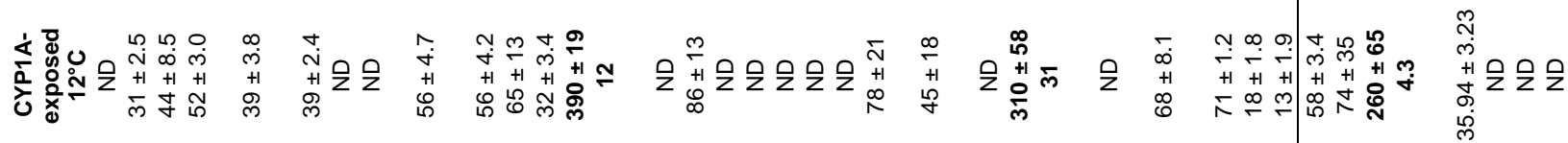

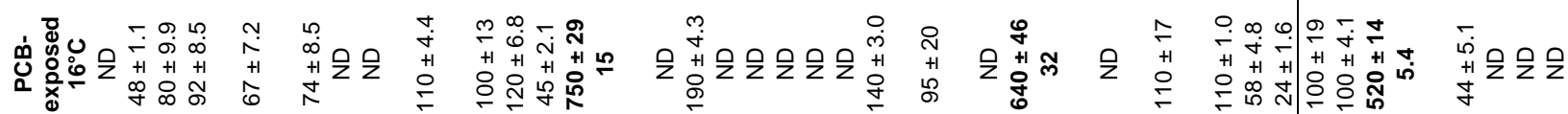

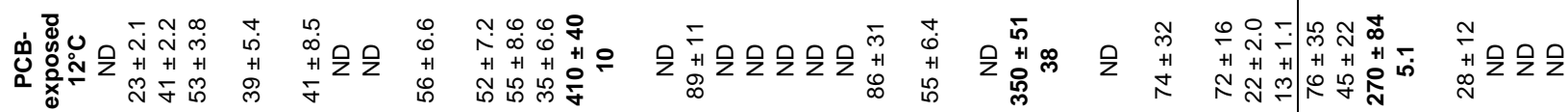

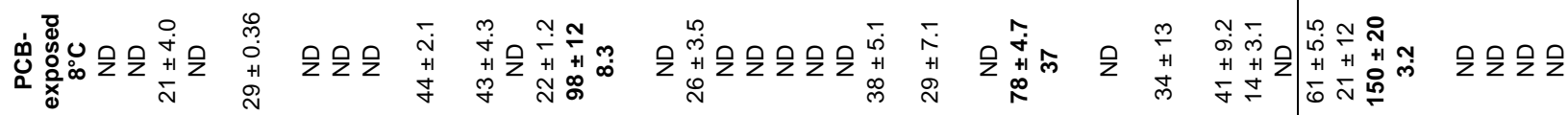

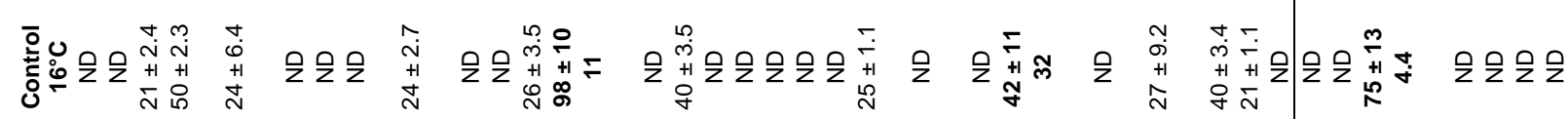

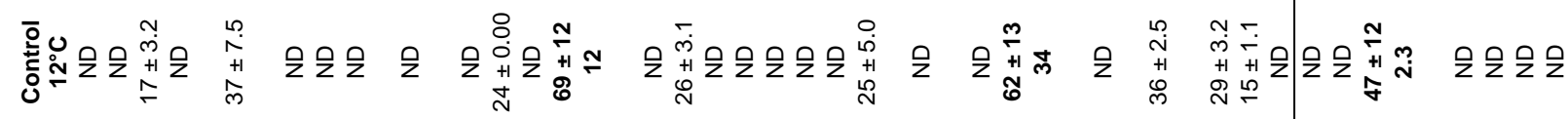

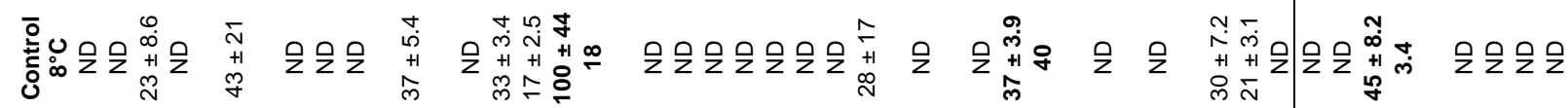
$\begin{array}{ll} & \\ & \\ 0\end{array}$

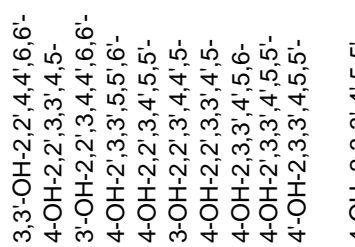

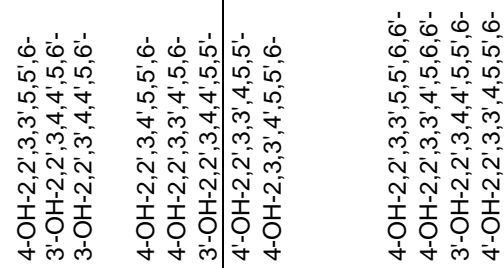

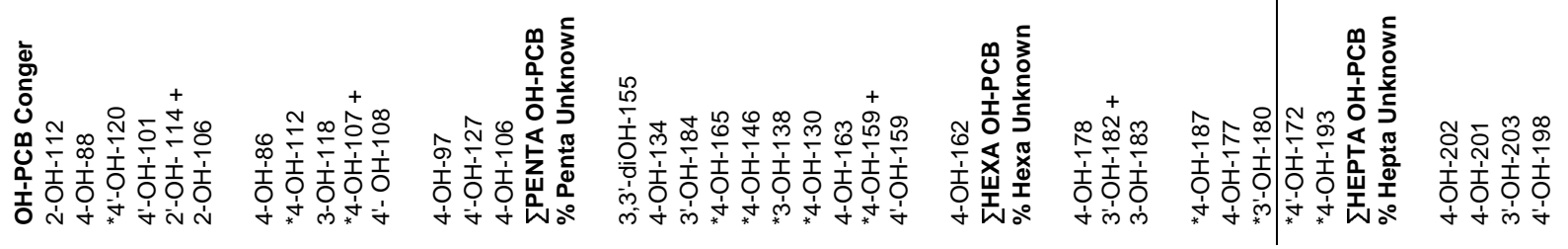




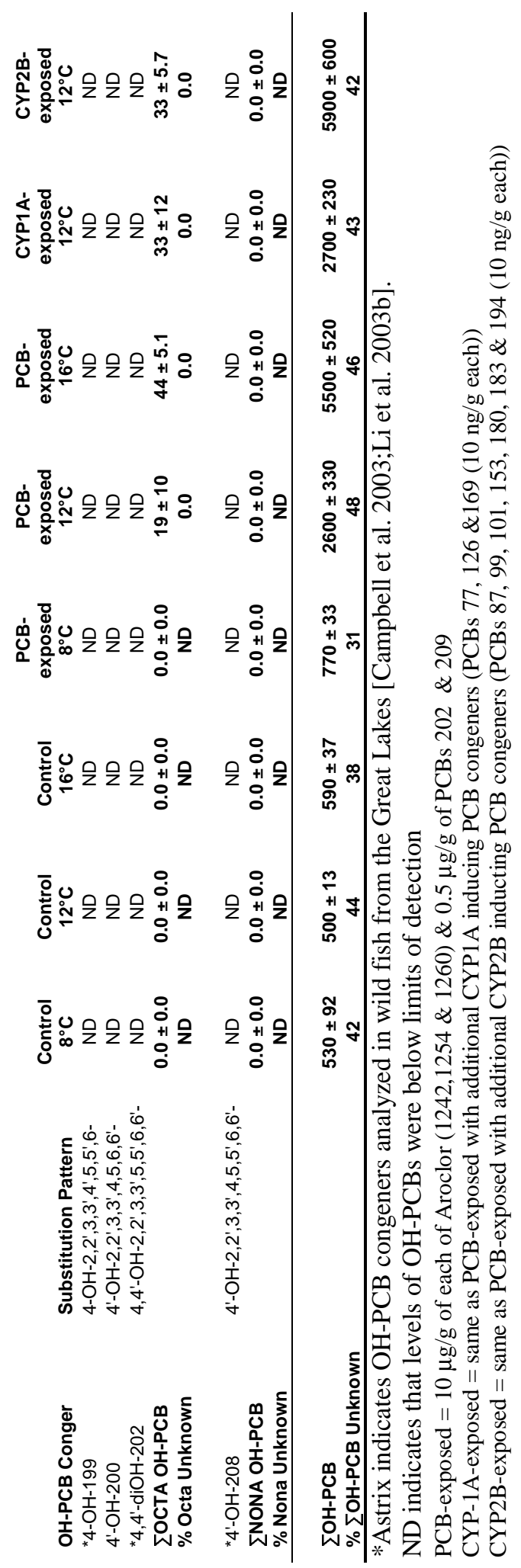




\section{References}

1. Buckman, A. H., Wong, C. S., Chow, E. A., Brown, S. B., Solomon, K. R., and Fisk, A. T. Biotransformation of polychlorinated biphenyls (PCBs) and bioformation of hydroxylated PCBs in fish. Aquat Toxicol. 2006, 78, 176-185.

2. Niimi, A.J. and Oliver, B.G. Biological half-lives of polychlorinated biphenyl (PCB) congeners in whole fish and muscle of rainbow trout (Salmo gairdneri). Can. J. Fish. Aquat. Sci. $1983,40,1388-1394$.

3. National Laboratory for Environmental Testing. Protocol for the fractionation and analysis of OCs/PCB/toxaphene. Protocol 97-101. 1997. Environment Canada.

4. Sandau, C. D., Ayotte, P., Dewailly, E., Duffe, J., and Norstrom, R. J. Analysis of hydroxylated metabolites of PCBs (OH-PCBs) and other chlorinated phenolic compounds in whole blood from Canadian Inuit. Environ.Health Perspect. 2000, 108, 611-616.

5. Hodson, P.V., Efler, S., Wilson, J.Y., El-Shaarawi, A., Maj, M., and Williams, T.G. Measuring the potency of pulp mill effluents for induction of hepatic mixed-function oxygenase activity in fish. J. Toxicol. Environ. Chem. 1996, 49, 83-110.

6. Fragoso, N.M., Parrott, J.L., Hahn, M.E., and Hodson, P.V. Chronic retene exposure causes sustained induction of CYP1A activity and protein in rainbow trout (Oncorhynchus mykiss). Environ. Toxicol. Chem. 1998, 17, 2347-2353.

7. Letcher,R.J., Klasson-Wehler, E., and Bergman, A. New types of persistent halogenated compounds. In: Paasivirta,J. (ed.), The handbook of environmental chemistry, Springer-Verlag, 2000. pp. 315-360. 